\title{
Correlation between Stigma and Adherence to ART among HIV-Positive Adolescents: A Cross- Sectional Study
}

\author{
Shaily B Surti',]K Kosambiya ${ }^{2}$, Patni MohamedAnas MohamedFaruk ${ }^{3}$
}

${ }^{1}$ Assistant Professor, Dept. of Community Medicine, Parul Institute of Medical Science and Research, Parul University Gujarat, India. ${ }^{2}$ Professor \& Head, ${ }^{3}$ Assistant Professor, Dept. of Community Medicine, Government Medical College, Surat, Gujarat, India. DOI: https://doi.org/10.24321/2349.2880.202101

I $\quad \mathbf{N} \quad \mathbf{F} \quad \mathbf{O}$

\section{Corresponding Author:}

Shaily B Surti, Parul Institute of Medical Sciences and Research.

E-mail Id:

sejusurti@gmail.com

Orcid Id:

https://orcid.org/0000-0003-0451-0879

How to cite this article:

Surti SB, Kosambiya JK, MohamedFaruk PMA. Correlation between Stigma and Adherence to ART among HIV-Positive Adolescents: A Cross-Sectional Study. Ind J Youth Adol Health. 2021;8(1):1-7.

Date of Submission: 2021-02-17

Date of Acceptance: 2021-03-15

\section{$\begin{array}{llllllll}\mathbf{A} & \mathbf{B} & \mathbf{S} & \mathbf{T} & \mathbf{R} & \mathbf{A} & \mathbf{C} & \mathbf{T}\end{array}$}

\begin{abstract}
Despite the prominence of youth on the global agenda, young people are often left behind in national HIV responses. UNAIDS estimates indicate that AIDS-related deaths among young people are increasing. One of the reasons for this is poor prioritization of adolescents in national plans for scale-up of HIV testing, treatment and counseling services. The objectives of the current study was to: (1) To understand the social issues such as stigma and disclosure faced by them (2) To document the adherence to ART among them and study the effect of stigma on it. The cross-sectional study was conducted at HIV clinic, at ART Centre, Surat (Tertiary Care Level Institute) among adolescents between age-group 13-19 years during December-2015 to February-2016. By purposive sampling following desk review of Hospital data, 105 participants were enrolled. Frequency distribution, Factor analysis and Correlation were utilized for analysis. Around $80 \%$ feared that they will lose their friends if they came to know about their serostatus. Factor analysis yielded 2 factors- Blaming and Distancing. These two factor scores were found significantly correlated to adherence to ART. Only 7\% chose to share about the status with friends outside the family. The study findings suggest that there is a need for prioritizing adolescent health among seropositives as their difficulties are different than children and adults in handling social issues like stigma due to their age and peer pressure. The lack of knowledge and fear of stigma among them if not addressed may lead to poor adherence to treatment and therefore, clinical complications.
\end{abstract}

Keywords: HIV-Positive Adolescents, Stigma, Knowledge, HIV Transmission, Adherence to ART

\section{Introduction}

According to UNAIDS estimates, in 2019, the number of adolescents infected with the Human Immunodeficiency Virus (HIV) would be 1.6 million.1 In 2018 alone, 190,000
$(59,000-380,000)$ adolescents between the ages of 10 and 19 years were HIV-infected. 2 In India, in 2017, 21,00,000 youth were HIV-infected.3

As children reach adolescence and begin risk-taking 
behaviours, knowledge about the disease becomes essential for both personal health maintenance and HIV prevention within the larger population. Disclosed HIV status has been identified as one of the factors associated with better adherence.4,5 It also becomes important to know how much they share with their peers and friends outside family which indirectly represents the stigma they are feeling.

AIDS-related stigma and discrimination refer to prejudice, negative attitudes, abuse and treatment directed at people living with HIV and Acquired Immunodeficiency Syndrome (AIDS). Mental health may be jeopardized due to stigma.6 This becomes especially important for adolescents as they are coping with many other physical and mental challenges. It may lessen their motivation to maintain optimal health; they conceal their illness from others and develop social anxiety due to HIV-positive status; and it may cause lapses in the adherence when there is a concern that an acquaintance may witness pill-taking, leading to unwanted questions about a person's health and, potentially, an unexpected "outing" as being HIV-positive.7

Adherence to Anti-Retroviral Therapy (ART) is important for all adults, adolescents and children. However, for HIVinfected adolescents, there are some additional factors and particular challenges in maintaining adherence to ART.8 The current study was planned to study the stigma, disclosure, and adherence to treatment simultaneously which has not been conductedpreviously in India especially among HIV-positive adolescents who have their specific needs and issues in comparison to adults and children.

\section{Objectives}

- To understand the social issues suchas stigma and disclosure faced by HIV-positive adolescents

- To document the adherence to ART among them and study the effect of stigma on it

- To assess the level of knowledge about HIV transmission among HIV-positive adolescents

\section{Methodology}

This is a cross-sectional study among adolescents who were HIV-infected and were attending ART Clinic. The study was conducted at an HIV clinic, at ART Centre, Surat (Tertiary Care Level Institute) among adolescents between the agegroup of 13-19 years from December 2015 to February 2016.

A deskreview of ART Centre data, Surat of adolescents who are registered at ART centre $(n=143)$ and belong to the agegroup of 13-19 years was conducted. Purposive sampling was adopted. Participants ( $n=105)$ who were alive, were on Pre-ART/ART, had disclosed their status, and had givenconsent for the interview were included in the study. Those adolescents who were unknown about their status were excluded from the study. They were approached for interviews at the ART Centre, New Civil Hospital, Surat when they come for their treatment and counselling. Data collection tools included a semi-structured questionnaire, case records (ART cards), and the modified HIV Stigma Scale.

The study was approved by the Human Research Ethics Committee (Institutional Ethics Committee), Government Medical College, Surat, and NACO (National AIDS Control Organisation). Identities of the participants were protected at all times and the participation was voluntary.

The Cronbach's alpha of the modified HIV Stigma Scale for the present study was found to be 0.773 . A Principal axis Factor Analysis was conducted on 12-items with oblique rotation (direct oblimin). The Kaiser-Meyer-Olkin measure verified the sampling adequacy for the analysis, $\mathrm{KMO}=$ 0.75 (acceptable >0.5). Correlation analysis was done for studying the effect of stigma on adherence.

\section{Result}

As depicted in Table 1, the mean age of participants was 15.64 years (SD \pm 2.02 ). Majority of the participants were boys (67.9\%) followed by girls (32.1\%). Majority of the participants belonged to socio-economic class IV (36.8\%) and class III (31.1\%) followed by class V (17\%), class II (13.2\%), and Class I (1.9\%) based on AICPI of November 2015.Majority of the participants were on ART (95.3\%). Out of the total 105 participants, 91 (85.8\%) had acquired HIV by vertical transmission followed by blood transfusion 4 (3.8\%).

Table I.General and Clinical Information of Participants

\begin{tabular}{|c|c|c|}
\hline Variable & Categories & $\begin{array}{l}\text { Frequency (\%) } \\
\quad(n=105)\end{array}$ \\
\hline Age & Mean age & $15.64 \pm 2.02$ \\
\hline \multirow{2}{*}{ Sex } & Boy & 72 (67.9) \\
\hline & Girl & $33(32.1)$ \\
\hline \multirow{5}{*}{$\begin{array}{c}\text { Socio-economic } \\
\text { class (Modified } \\
\text { Prasad } \\
\text { Classification) }\end{array}$} & 1 & $2(1.9)$ \\
\hline & II & $14(13.2)$ \\
\hline & III & $33(31.1)$ \\
\hline & IV & $38(36.8)$ \\
\hline & V & $18(17.0)$ \\
\hline \multirow{2}{*}{ ART status } & Pre-ART & $5(4.7)$ \\
\hline & On ART & $100(95.3)$ \\
\hline \multirow{6}{*}{$\begin{array}{c}\text { Route of } \\
\text { transmission }\end{array}$} & Vertical & $91(85.8)$ \\
\hline & $\begin{array}{l}\text { Homosexual } \\
\text { intercourse }\end{array}$ & 1 (0.9) \\
\hline & $\begin{array}{c}\text { Heterosexual } \\
\text { intercourse }\end{array}$ & $1(0.9)$ \\
\hline & Intravenous & 2 (1.9) \\
\hline & Blood transfusion & $4(3.8)$ \\
\hline & Unknown & $6(5.6)$ \\
\hline
\end{tabular}


About one-third of the participants (29.5\%) were aware of all the 4 modes of transmission while 20 (19\%) were not aware of any mode of transmission of HIV which is depicted in Table 2.

Table 2.Distribution of Participants according to Knowledge of Route of Transmission of HIV

\begin{tabular}{|c|c|c|}
\hline Variable & Categories & Frequency (\%) $\mathbf{n = 1 0 5 )}$ \\
\hline \multirow{4}{*}{ Knowledge* } & P0 & $20(19.0)$ \\
\cline { 2 - 3 } & P1 & $6(5.7)$ \\
\cline { 2 - 3 } & P2 & $19(18.1)$ \\
\cline { 2 - 3 } & P3 & $29(27.6)$ \\
\cline { 2 - 3 } & P4 & $31(29.5)$ \\
\hline
\end{tabular}

*P0 - knows no mode of transmission

P1 - knows atleast 1 of 4 modes of transmission

P2 - knows atleast 2 of 4 modes of transmission

P3 - knows atleast 3 of 4 modes of transmission

P4 - knows all 4 modes of transmission

As summarised in Table 3, almost two-thirds of the participants (69.5\%) reported rarely feeling blamed by others for their illness. Almost half of the participants
(26.7\%) always felt the fear that they might be expelled from their school if the school came to know about their illness. Around one-third of the participants (33.3\%) reported often avoiding getting treatment due to the fear that someone might find out about their illness. Out of the total participants, $41.9 \%$ always felt that they will lose their friends if they came to know about their illness.

A principal axis factor analysis was run to obtain eigenvalues for each factor in the data. Two factors had eigenvalues over Kaiser's criterion of 1 and in combination explained $47 \%$ of the variance. The scree plot was ambiguous and showed inflexions that would justify retaining either 2 or 4 factors. We retained 2 factors based on the convergence of the scree plot and Kaiser's criterion on the value. Table 4 shows the factor loadings after rotation. The items that cluster on the same factor suggest that Factor 1 represents blaming, and Factor 2 represents distancing. Factor 1 included the feeling of blame inflicted by self and others for suffering from the disease for which most were not responsible themselves as the majority were infected by vertical transmission. Factor 2 included fear of distancing/ shunning by society (school, residence) due to their positive status.

Table 3.Frequency Distribution of Responses to Items on the Modified HIV Stigma Scale $(n=105)$

\begin{tabular}{|c|c|c|c|c|c|}
\hline Item & Not at all (\%) & Rarely (\%) & Sometimes (\%) & Often (\%) & Always (\%) \\
\hline $\begin{array}{c}\text { Do you feel blamed by others for your } \\
\text { illness? }\end{array}$ & $20(19)$ & $73(69.5)$ & $4(3.8)$ & $5(4.8)$ & $3(2.9)$ \\
\hline Do you feel ashamed of your illness? & $20(19)$ & $70(66.7)$ & $2(1.9)$ & $6(5.7)$ & $7(6.7)$ \\
\hline $\begin{array}{c}\text { Do you think your illness was a punishment } \\
\text { for things you have done in the past? }\end{array}$ & $18(17.1)$ & $63(60.0)$ & $2(1.9)$ & $9(8.6)$ & $13(12.4)$ \\
\hline $\begin{array}{c}\text { Do you fear that you might be expelled from } \\
\text { your school if someone found out about } \\
\text { your illness? }\end{array}$ & $4(3.8)$ & $13(12.4)$ & $9(8.6)$ & $30(28.6)$ & $49(26.7)$ \\
\hline $\begin{array}{c}\text { Do you feel compelled to change your } \\
\text { residence because of your illness? }\end{array}$ & $9(8.6)$ & $59(56.2)$ & $10(9.5)$ & $14(13.3)$ & $13(12.4)$ \\
\hline $\begin{array}{c}\text { Do you avoid getting treatment because } \\
\text { someone might find out } \\
\text { about your illness? }\end{array}$ & $4(3.8)$ & $42(40)$ & $10(9.5)$ & $35(33.3)$ & $14(13.4)$ \\
\hline $\begin{array}{c}\text { Do you fear that people would hurt your } \\
\text { family if they learnt about your illness? }\end{array}$ & $16(15.2)$ & $59(56.2)$ & $4(3.8)$ & $12(11.4)$ & $14(13.4)$ \\
\hline $\begin{array}{c}\text { Do you think other people are } \\
\text { uncomfortable being with you? }\end{array}$ & $21(20)$ & $65(61.9)$ & $5(4.8)$ & $6(5.7)$ & $8(7.6)$ \\
\hline $\begin{array}{c}\text { Do you feel people avoid you because of } \\
\text { your illness? }\end{array}$ & $20(19)$ & $68(64.8)$ & $12(11.4)$ & $3(2.9)$ & $2(1.9)$ \\
\hline $\begin{array}{c}\text { Do you fear you would lose your friends if } \\
\text { they learnt about your illness? }\end{array}$ & $2(1.9)$ & $7(6.7)$ & $13(12.4)$ & $39(37.1)$ & $35(41.9)$ \\
\hline $\begin{array}{c}\text { Do you feel you wouldn't get as good health } \\
\text { care if people knew about } \\
\text { your illness? }\end{array}$ & $5(4.8)$ & $54(51.4)$ & $11(10.5)$ & $18(17.1)$ & $17(16.2)$ \\
\hline \begin{tabular}{c} 
D. \\
\hline
\end{tabular}
\end{tabular}


Table 4.Factor Structure of the Modified HIV Stigma Scale $(n=105)$

\begin{tabular}{|c|c|c|c|c|c|}
\hline Factor & Items & $\begin{array}{l}\text { Factor } \\
\text { loadings }\end{array}$ & $\begin{array}{l}\text { Cronbach's } \\
\text { alpha }\end{array}$ & Eigenvalues & $\begin{array}{c}\% \text { of } \\
\text { variance }\end{array}$ \\
\hline \multirow{5}{*}{ Blaming } & $\begin{array}{l}\text { Do you think other people are uncomfortable being } \\
\text { with you? }\end{array}$ & 0.850 & \multirow{5}{*}{0.764} & \multirow{5}{*}{3.59} & \multirow{5}{*}{32.65} \\
\hline & $\begin{array}{l}\text { Do you feel people avoid you because of your } \\
\text { illness? }\end{array}$ & 0.780 & & & \\
\hline & Do you feel blamed by others for your illness? & 0.773 & & & \\
\hline & Do you feel ashamed of your illness? & 0.695 & & & \\
\hline & $\begin{array}{c}\text { Do you think your illness was a punishment for } \\
\text { things you have done in the past? }\end{array}$ & 0.495 & & & \\
\hline \multirow{6}{*}{ Distancing } & $\begin{array}{l}\text { Do you avoid getting treatment because someone } \\
\text { might find out about your illness? }\end{array}$ & 0.805 & \multirow{6}{*}{0.698} & \multirow{6}{*}{1.65} & \multirow{6}{*}{15.04} \\
\hline & $\begin{array}{l}\text { Do you fear that you might be expelled from your } \\
\text { school if someone found out about your illness? }\end{array}$ & 0.772 & & & \\
\hline & $\begin{array}{l}\text { Do you fear you would lose your friends if they } \\
\text { learnt about your illness? }\end{array}$ & 0.662 & & & \\
\hline & $\begin{array}{l}\text { Do you feel compelled to change your residence } \\
\text { because of your illness? }\end{array}$ & 0.592 & & & \\
\hline & $\begin{array}{c}\text { Do you fear that people would hurt your family if } \\
\text { they learnt about your illness? }\end{array}$ & 0.503 & & & \\
\hline & $\begin{array}{l}\text { Do you feel you wouldn't get as good health care if } \\
\text { people knew about your illness? }\end{array}$ & 0.327 & & & \\
\hline
\end{tabular}

Table 5, shows that the mean age of the disclosure among the participants was 12.47 years $(S D \pm 2.8)$. Majority of the participants were disclosed about their status by a firstdegree relative (mostly mother or father) (41.9\%) followed by a counsellor (33.3\%) and doctor (14.3\%). Few participants $(7.7 \%)$ reported that they became aware ofHIV by looking at posters or meetings held at the hospital (ART Centre). Majority of the participants $(85.7 \%)$ have shared about their positive serostatus to all the members of the family only; followed by participants who have disclosed it to a few members of the family (7.6\%), and participants who have disclosed it to a few friends in addition to their family members (6.7\%).

Out of 100 participants on ART, $13 \%$ were on second-line regime whereas $87 \%$ were on first-line regime as described in Table 6.Adherence was collected as continuous data from case records and then categorized into 4 categories. About two-thirds of the participants (62\%) had $100 \%$ adherence, followed by $96-99 \%$ adherence $(20 \%)$, and 80-95\% adherence (16\%).

Table 5.Distribution of Participants according to their HIV-positive Status Disclosure and Related Information

\begin{tabular}{|c|c|c|}
\hline Variable & Categories & Frequency (\%) $\mathbf{n = 1 0 5}$ \\
\hline Age of disclosure & Mean age & $12.47 \pm 2.8$ years \\
\hline \multirow{4}{*}{ Disclosure done by } & First-degree relative & $44(41.9)$ \\
\cline { 2 - 3 } & Second-degree relative & $3(2.9)$ \\
\cline { 2 - 3 } & Counsellor & $35(33.3)$ \\
\cline { 2 - 3 } & Doctor & $15(14.3)$ \\
\hline \multirow{3}{*}{ Status shared with } & All members of the family & $8(7.7)$ \\
\cline { 2 - 3 } & A few members of the family & $90(85.7)$ \\
\cline { 2 - 3 } & Family and a few friends & $8(7.6)$ \\
\hline
\end{tabular}


Table 6.Distribution of Participants according to Adherence

\begin{tabular}{|c|c|c|}
\hline Variable & Categories & Frequency (\%) \\
\hline $\begin{array}{c}\text { Type of regimen } \\
(\mathrm{n}=100)\end{array}$ & First-line & $87(87.0)$ \\
\cline { 2 - 3 } & Second-line & $13(13.0)$ \\
\hline \multirow{3}{*}{$\begin{array}{c}\text { Adherence }(\%) * \\
n=100\end{array}$} & $100 \%$ & $62(62.0)$ \\
\cline { 2 - 3 } & $96-99 \%$ & $20(20.0)$ \\
\cline { 2 - 3 } & $80-95 \%$ & $16(16.0)$ \\
\cline { 2 - 3 } & $<80 \%$ & $2(2.0)$ \\
\hline
\end{tabular}

*Formula for adherence-

$100 \%$-no missed doses in last 30 days

$96-99 \%-<3$ missed doses in last 30 days

$80-95 \%$ - 3-12 missed doses in last 30 days

$<80 \%$ - $>12$ missed doses in last 30 days

The correlation coefficientsby Pearson correlation between adherence and factor score of factor 1-blaming and factor 2-distancing of Stigma scale were found statistically significant as 0.260 and 0.235 (P-value $<0.05$ ) respectively. Higher the blaming and distancing factor, more the chances of missing their doses i.e., lower the adherence to ART.

\section{Discussion}

The present study revealed that the mean age of participants was 15.64 years (SD \pm 2.02 ). Majority of the participants were boys (67.9\%) followed by girls (32.1\%). Out of the total 105 participants, 91 (85.8\%) had acquired HIV by vertical transmission followed by blood transfusion (4 (3.8\%)), 2 (1.9\%) had acquired HIV by the intravenous route, $1(0.9 \%)$ by homosexual route, $1(0.9 \%)$ by heterosexual route, and for $6(5.6 \%)$, route of transmission wasunknown. A study conducted by Marfatia YS etal. in 2008 at Vadodara, India reported that $64 \%$ of HIV-positive adolescents were infected by vertical transmission, followed by $12 \%$ by blood transfusion, $12 \%$ by sexual transmission, and for $12 \%$,the reason was unknown.9

About one-third of the participants (29.5\%) were aware ofall 4 modes of transmission while 20 (19\%) were not aware of any mode of transmission of HIV. Out of 105 participants, 39(37.4\%) knew about the sexual route of transmission whereas 75 (71.4\%) knew about mother to child transmission. Reaching youngsters at an impressionable age before they become sexually active can lay the foundation for a responsible lifestyle, including sex and marriage.A national study by NACO/UNICEF among young people (15-24 years) found that $83 \%$ of therespondents knew of at least two correct modes of transmission of HIV.10 Nearly half of them reported using condoms in the last casual sex and consistent condom use is much lower.10The knowledge becomes extremely important for adherence to treatment and future preventive behaviour.
The items of the modified HIV Stigma Scale that cluster on the same factor suggest that Factor 1 represents blaming, and Factor 2 represents distancing. Similar results were found in studies conducted worldwide among HIV-positive people of all agegroups.11-13

A study conducted by Tanney $\mathrm{M}$ etal. reported that behavioural infection, older age, more problem behaviours, and greater stigma, each contributed to the prediction of higher depression scores in Youth Living with HIV.14

Majority of the participants were disclosed about their status by a first-degree relative (mostly mother or father) $(41.9 \%)$, followed by a counsellor $(33.3 \%)$, and doctor (14.3\%), whereas few participants $(7.7 \%)$ reported that they became aware ofHIV by looking at posters or meetings held at the hospital (ART Centre) in the current study. Bhattacharya etal. reported that disclosure was most frequently done by parents [51/60 (85\%)] at a mean age of $9.1 \pm 1.4$ years. 15 Arrive E et al. reported disclosure by parents as 33\% among all HIV infected adolescents, $27.8 \%$ by doctors, and $5 \%$ by psychologists or social workers. 16

In the present study, participants who have disclosed to a few friends in addition to their family members are $6.7 \%$. Nostlinger Cetal. in 2015 in Eastern Africa reported that 19.9\% of HIV-positive adolescents had disclosed their status to peers, friends, and girl-or-boyfriends 17 which is higher than the present study findings.This can be due to poor knowledge and stigma among the current study participants.

It is well recognized that maximal adherence to the prescribed Anti Retro Viral (ARV) regimen is crucial for achieving and maintaining optimal antiretroviral response. In the present study, about two-thirds of the participants had $100 \%$ adherence (62\%) followed by $96-99 \%$ adherence (20\%), $80-95 \%$ adherence (16\%) and $<80 \%$ adherence (2\%). These results are much higher than the adherence reported by some studies. Gaur AH et al. reported $55 \%$ of HIV-infected youth as non-adherent to HAART.18A study conducted by Nyogea D etal. in Tanzania in 2015 reported that $70 \%$ of the participants had optimal adherence levels among HIV-positive adolescents.19 The reason for high adherence may be credited to the proper counselling and regular follow-up of the LFU (loss to follow-up) patients by the ART Centre of New Civil Hospital, Surat,though they did admit to avoiding taking medicines in front of acquaintances to avoid coming out with the status which was reflected by the correlation analysis between adherence and stigma scale factor scores for both the factors.

\section{Conclusion}

The level of knowledge among participants was found to be inadequate. A principal axis factor analysis conducted on the Modified HIV Stigma Scale and the items that cluster on the 
same factor suggest that Factor 1 represents blaming, and Factor 2 represents distancing. Factor 1 included the feeling of blame inflicted by self and others for their serostatus. Factor 2 included fear of distancing/shunning by society due to their positive status- at school, residence, while taking treatment, and from friends and neighbours. Despite the lack of knowledge and feeling of stigma, the adherence was found considerably good. But due to stigma, participants admitted avoiding taking treatment in front of others in fear of someone finding out and so a positive correlation was found between stigma and adherence. Disclosure results corroborated the findings of the Stigma scale as very few chose to share the status outside the family members to friends.

The findings suggest that there is a need forscaling up the measures which are specific for adolescents as their needs differ from children as well as adults. More steps for knowledge awareness can help in preventing further transmission in their adult life. The knowledge may also help alleviate their fears causing them to blame themselves and distancing themselves from others. Specific meetings every month at the ART Centre may be arranged for this agegroup to address their challenges. Specific counselling guidelines for adolescents will help in better management and coping with the issues faced by them.

\section{Conflict of Interest: None \\ Source of Funding: None \\ References}

1. UNAIDS. Global estimates. 2019. Available from: https://www.unaids.org/sites/default/files/media_ asset/2019-UNAIDS-data_en.pdf

2. UNICEF, UNICEF. Data: Monitoring the situation of children and women.2019. Available from: https:// data.unicef.org/resources/sowc-2019-statistical-tablesand-interactive-dashboard/

3. UNAIDS . Country report: India.2019. Available from: https://www.unaids.org/en/regionscountries/ countries/india

4. Bikaako-Kajura W, Luyirika E, Purcell DW, Downing J, Kaharuza F, Mermin J, Malamba S, Bunnell R. Disclosure of HIV status and adherence to daily drug regimens among HIV-infected children in Uganda. AIDS Behav.2006;10(4 Suppl):S85-93. [PubMed] [Google Scholar].

5. Haberer JE, Cook A, Walker AS, Ngambi M, Ferrier A, Mulenga V, Kityo C, Thomason M, Kadamba D, Chintu C, Gibb DM, Bangsberg DR. Excellent adherence to antiretrovirals in HIV+ Zambian children is compromised by disrupted routine, HIV nondisclosure, and paradoxical income effects. PLoS One.2011;6(4):e18505. [PubMed] [Google Scholar].
6. Major B,O'Brien LT. The social psychology of stigma. Annu Rev Psychol.2005;56:393-421. [PubMed] [Google Scholar].

7. Weiser S, Wolfe W, Bangsberg D, Thior I, Gilbert P, Makhema J, Kebaabetswe P, Dickenson D, Mompati $\mathrm{K}$, Essex M, Marlink R. Barriers to antiretroviral adherence for patients living with HIV infection and AIDS in Botswana. J Acquir Immune Defic Syndr.2003;34(3):281-8. [PubMed] [Google Scholar]

8. Nichols S. Neuropsychology of HIV in children and adolescents. Psychology and AIDS Exchange Newsletter.2014.

9. Modi M, Sharma N, Sharma A, Marfatia YS. HIV infection in adolescents: A rising concern. Indian Journal of Sexually Transmitted Diseases and AIDS.2008;29(2):7375. [Google Scholar].

10. National behavioural Surveillance Survey 2006, National AIDS Control Organisation, India. Available from: http:// naco.gov.in/sites/default/files/Youth_report_1.pdf

11. Sekoni AO, Obidike OR, Balogun MR. Stigma, medication adherence and coping mechanism among people living with HIV attending General Hospital, Lagos Island, Nigeria. Afr J Prm Health Care Fam Med. 2012;4(1):417. [Google Scholar].

12. Bharat S. A systematic review of HIV/AIDS-related stigma and discrimination in India: Current understanding and future needs. SAHARA J. 2011;8(3):138-49. [PubMed] [Google Scholar].

13. Malcolm A, Aggleton P, Bronfman M, Galvao J, Mane P, Verrall J. HIV-related stigmatization and discrimination: Its forms and contexts. Critical Public Health.1998;8(4):347-370. [Google Scholar].

14. Tanney MR, Naar-King S, MacDonnel K. Depression and Stigma in High Risk Youth Living with HIV: A Multisite Study. Journal of Pediatric Health Care.2012;26(4):300305. [Google Scholar].

15. Bhattacharya M, Dubey AP, Sharma M. Patterns of Diagnosis Disclosure and its Correlates in HIV-Infected North Indian Children. J Trop Pediatr. 2011;57(6):405411. [PubMed] [Google Scholar].

16. Arrive $E$, Dicko F, Amghar $H$, Aka AE, Dior $H$, Bouah B, Traore M, Ogbo P, Dago-Akribi HA, Eboua TKF, Kouakou K, Sy HS, Alioum A, Dabis F, Ekouevi DK, Leroy V, Pediatric IeDEA West Africa Working Group. HIV Status Disclosure and Retention in Care in HIV-Infected Adolescents on Antiretroviral Therapy (ART) in West Africa. PLoS One.2012;7(3):e33690. [PubMed] [Google Scholar].

17. Nostlinger C, Bakeera-Kitaka S, Buyze J, Loos J, Buve A. Factors influencing social self-disclosure among adolescents living with HIV in Eastern Africa. AIDS Care.2015;27 Suppl 1:36-46. [PubMed] [Google Scholar]. 
18. Gaur AH, Belzer M, Britto P, Garvie PA, Hu C, Graham B, Neely M, McSherry G, Spector SA, Flynn PM, Pediatric AIDS Clinical Trials Group. Directly observed therapy (DOT) for nonadherent HIV-infected youth: lessons learned, challenges ahead. AIDS Res Hum Retroviruses.2010;26(9):947-53. [PubMed] [Google Scholar].

19. Nyogea D, Mtenga S, Henning L, Franzeck FC, Glass TR, Letang E, Tanner M, Geubbels E. Determinants of antiretroviral adherence among HIV positive children and teenagers in rural Tanzania: a mixed methods study. BMC Infectious Diseases.2015;15(1):28. [Google Scholar]. 